\title{
Development of Chemosensitivity of an Identified Insect Interneurone ${ }^{1}$
}

\author{
J. M. BLAGBURN, ${ }^{*}$ D. J. BEADLE, ${ }^{\star}$ AND D. B. SATTELLE ${ }^{2}$
}

* A. F. R. C. Unit of Insect Neurophysiology and Pharmacology, Department of Zoology, University of Cambridge, Downing Street, Cambridge CB2 3EJ, and $\ddagger$ Department of Biological Sciences, Thames Polytechnic, Wellington St., Woolwich, London SE18, England

\begin{abstract}
Characteristic features of cockroach embryos (Periplaneta americana) are determined for different stages in development. Morphological changes in giant interneurone 2 (GI 2) in the terminal abdominal ganglion during embryogenesis are described based on cobalt injections. A sequential proliferation of branches preceded by filopodial extension is observed between 45 and $80 \%$ embryogenesis, by which time the characteristic arborization of the first instar cell is established. The cholinergic agonist carbamylcholine was ionophoretically applied to the cell body and dendritic region of Gl 2 at various stages in development, and the responses were recorded intracellularly. Chemosensitivity of GI 2 appears at 40 to $45 \%$ embryogenesis, to a similar degree in both cell body and dendrites. The sensitivity of these areas subsequently diverges, and after the 60 to $65 \%$ stage, the dendrites are approximately 1000 times more sensitive than the cell body. At 80 to $85 \%$ embryogenesis, there is a temporary peak in dendritic sensitivity, and cell body sensitivity increases during postembryonic development. The changes in sensitivity take place before synaptogenesis, and the decline in dendritic sensitivity after the $80 \%$ stage may be related to synaptic maturation.
\end{abstract}

Identified neuronal pathways in the nervous system of insects are well suited for studies of synaptogenesis and neuronal interactions during development. The cercal afferent, giant interneurone pathways in Orthoptera and Dictyoptera, which play a part in mediating the escape response to mechanical stimulation of sensory receptors on the cerci, have been investigated by several laboratories (Roeder, 1948; Edwards and Palka, 1974; Mendenhall and Murphey, 1974; Matsumoto and Murphey, 1977; Ritzmann and Camhi, 1978; Camhi et al., 1978; Murphey et al., 1983). Although the development of the sensory afferent and interneurone branching patterns in Schistocerca americana have been described in most detail (Shankland 1981a, b; Shankland and Goodman, 1982a), the equivalent neurones in the cockroach Periplaneta americana are excellent candidates for developmental studies because, in the adult, aspects of their anatomy, physiology, and pharmacology and their role in behavior have been described (Callec 1974; Callec et al., 1980; Harrow et al. 1980; Daley et al., 1981; Sattelle et al., 1980, 1983). Moreover, it has been shown that the first instar nymphs of $P$. americana possess only

Received February 10, 1984; Revised September 18, 1984;

Accepted September 20, 1984

\footnotetext{
${ }^{1}$ This work was supported by Agriculture and Food Research Council of the United Kingdom.

${ }^{2}$ To whom correspondence should be addressed.
}

two functional filiform hair sensilla on each cercus (Bugnion, 1921; Dagan and Volman, 1982) giving rise to large identifiable axons (Blagburn and Beadle, 1982) which form synaptic connections with the giant interneurones (Blagburn et al., 1984).

At cercal afterent, giant interneurone synapses in the adult cockroach ACh is the likely transmitter (Shankland et al., 1971; Callec, 1974; Sattelle et al., 1976; Sattelle 1978; Sattelle et al., 1983). Since it has been widely postulated that receptors for transmitter substances are involved in the formation and maintenance of synapses (Changeux and Danchin, 1977; Freeman, 1977), it is important to compare the chemosensitivity of the postsynaptic neurones throughout their development with the temporal pattern of synapse formation. Here we investigate the suitability of the developing cercal afferent, giant interneurone system of $P$. americana for this type of study.

Binding studies employing $\alpha$-bungarotoxin on the developing antennal lobes of Manduca sexta revealed a gradual rise in receptor density during development that was unaffected by deafferentation (Sanes et al., 1977; Hildebrand et al., 1979). Electrophysiological studies of chemosensitivity in dorsal unpaired median (DUM) neurones of Schistocerca nitens showed that ACh and GABA sensitivity first appears at $40 \%$ embryogenesis, along with axonal growth (Goodman and Spitzer, 1979; 1980; Goodman et al., 1979). At this time, the whole cell becomes sensitive, but chemosensitivity apparently decreases slightly as synaptic inputs appear at $75 \%$ embryogenesis. Recently, ionophoresis of ACh and related compounds has been used to quantify the sensitivity to these ligands of identified interneurones and a motoneurone in the cockroach (Sattelle et al., 1980; Harrow et al., 1982; Callec et al., 1982; David and Pitman, 1982; Harrow and Sattelle; 1983; David and Sattelle, 1984). In the present study on giant interneurone 2 (Gl 2), the developing morphology of the cell during embryogenesis is investigated by intracellular cobalt injection, and the development of chemosensitivity is followed by the ionophoretic application of the cholinergic agonist carbamylcholine onto the cell body (soma) and the dendrites.

\section{Materials and Methods}

Oothecae projecting from female cockroaches were harvested daily and could be dated to within $24 \mathrm{hr}$. Each daily collection was stored in separate Petri dishes containing damp cotton wool, at a temperature of $30^{\circ} \mathrm{C}$. Their age was expressed as a percentage of the total time to hatching (normally 31 days). The designations $A 1$ to $A 6$ are used for abdominal ganglia in the adult cockroach; $A_{1}$ to $A_{11}$ are used to refer to ganglion rudiments present in the embryonic abdominal CNS. The terminal ganglion refers to the postfusion ganglion (A6) formed from rudiments $A_{7}$ to $A_{11}$.

Newly hatched first instar nymphs or embryos of the desired age were placed in saline of the following composition: $150 \mathrm{mM} \mathrm{NaCl}, 3.1 \mathrm{~mm} \mathrm{KCl}, 5.4$ $\mathrm{mM} \mathrm{CaCl}, 5 \mathrm{~mm}$ HEPES buffer, $\mathrm{pH} 7.4$ (based on Callec and Sattelle, 1973). Following removal of the legs and gut, the nerve cord (still attached to the head, caudal segments, and cerci) was transferred to saline inside a rubberwalled chamber constructed on a glass microscope slide. The CNS was anchored by attaching the head together with the thoracic and caudal 
scgments to petrolcum jelly. Trachcal trunks and the stumps of nerves 7 and 8 (nomenclature of Roeder et al., 1960) were removed from the terminal abdominal (A6) ganglion, which was held in position by maintaining the interganglionic connectives and nerves 9, 10, and 11 under slight tension. It was often necessary to crush or remove the remaining musculature of the caudal segments to prevent tissue movements. The ganglion was desheathed using fine forceps and finally secured in the experimental chamber, dorsal side uppermost. For studies on adult insects, a preparation including abdominal ganglia $A 5$ to $A 6$ was dissected out and anchored by the interganglionic connectives and cercal nerves, using petroleum jelly. A6 was then desheathed.

Isolated preparations were viewed with a Zeiss $\times 40$ water immersion lens using differential interference contrast (Nomarski) optics. Electrical isolation of the objective from the body of the microscope was achieved with a Perspex insert. A gravity perfusion system maintained a constant flow of saline (approximately $1 \mathrm{ml} \cdot \mathrm{min}^{-1}$ ). The soma of $\mathrm{Gl} 2$ was identified by its characteristic size, location, and appearance. Although, in the adult, the thickness of the tissue provided optical conditions that were far from ideal, it was nevertheless possible to recognize Gl 2 . The cell body was impaled with 80 - to 150 -megohm glass microelectrodes containing $0.6 \mathrm{M} \mathrm{K}_{2} \mathrm{SO}_{4}+5$ $\mathrm{mM} \mathrm{KCl}$ (Thomas, 1978 ) or $1.0 \mathrm{M} \mathrm{KCl}+5 \mathrm{mM}$ Tris buffer $(\mathrm{pH} 7.3)$.

The cholinergic agonist carbamylcholine was applied ionophoretically to the cell body and to the dendrites of $\mathrm{Gl} 2$. In the case of cell body applications, tow-resistance glass micropipettes containing $1.0 \mathrm{M}$ carbamylcholine chloride (Sigma Chemical Co.) were moved to within $5 \mu \mathrm{m}$ of the cell membrane after the recording microelectrode had been inserted. During investigation of dendritic chemosensitivity, the ionophoretic micropipette was first inserted into the center of the contralateral neuropile, opposite the cell body, which was subsequently impaled with the recording microelectrode. A small retaining current ( $45 \mathrm{nA}$ ) prevented leakage of the agonist. Carbamylcholine was expelled by application of 0.2- to 2.0-sec, square, positive current pulses, monitored by a virtual-earth circuit, and subsequent responses were recorded on a pen recorder and oscilloscope. Dose response curves for carbamylcholine-induced depolarizations were constructed for both cell body and dendritic membranes of $G \mid 2$ at various stages after $40 \%$ embryogenesis. The amount of carbamylcholine released from the ionophoretic micropipette was measured using a blunt microelectrode the tip of which was filled with $\mathrm{K}^{+}$-sensitive liquid ion exchange resin (Corning LIE 477319) which is also sensitive to acetylcholine and carbamylcholine. The drug release was found to be linear using current pulses up to $20,000 \mathrm{nA}$.

The membrane input resistance $\left(R_{\text {in }}\right)$ was estimated by application of current pulses of $100 \mathrm{msec}$ or more duration via a bridge-circuit, while monitoring the transmembrane voltage.

For intracellular cobalt injection, the cell body of Gl 2 was impaled with 50 - to 100 -megohm microelectrodes containing $6 \%$ hexamminecobaltic chloride (Sigma Chemical Co.). Squarc, positive current putses $0.5 \mathrm{sec}$ in duration (at a frequency of $0.5 \mathrm{~Hz}$ and of $5 \mathrm{nA}$ amplitude) were passed through the electrode for 3 to $8 \mathrm{~min}$. The preparation was left for 10 to 15 min in saline to allow for distribution of cobalt, followed by precipitation with $\left(\mathrm{NH}_{4}\right)_{2} \mathrm{~S}$ and tissue fixation with alcoholic Bouin's fixative for $30 \mathrm{~min}$. Cobaltstained cells were silver-intensified using the whole-mount Timm's procedure of Bacon and Altman (1977), dehydrated in an alcohol series, cleared, and mounted in neutral Canada Balsam. The specimens were drawn with the aid of a Zeiss drawing tube.

\section{Results}

Embryonic staging in Periplaneta americana. The age of embryos is expressed as a percentage of the total time elapsed before halching (cf. Bentley et al., 1979) and several stages in embryogenesis are depicted in Figure 1. At 35\%, the embryo occupies the posterior half of the egg, having undergone katatrepsis at 30 to $35 \%$. It is fully segmented, and the antennal and limb buds are undergoing elongation. Pleuropodia remain on the first abdominal segment. The proctodeum has invaginated as far as the sixth abdominal segment, and this region is folded under the embryo. The CNS is not yet separate from the ventral surface and is composed of segmentally arranged ganglion rudiments. Five of these, in segments 7 to 11, will form the terminal abdominal ganglion, and fusion between ganglion rudiments $A_{9}, A_{10}$, and $A_{11}$ has begun. Some intersegmental fibers are present.

By $45 \%$, the embryo occupies approximately two-thirds of the embryo sac. The limbs are folded, and claws are developing Segmentation of the antennae and cerci has begun. Peristaltic contraction of the dorsal heart sinus and body wall are visible. At $50 \%$, traces of pigment are present in the eyes. Occasional flexures of the caudal segments are observed. The ganglion rudiment in the first abdominal segment $\left(A_{1}\right)$ fuses with that in the third thoracic segment, forming the metathoracic ganglion, while ganglion rudiment $A_{7}$ fuses with the terminal ganglion. Longitudinal and transverse fiber bundles are visible in the CNS, and peripheral nerves are present.

By $60 \%$, the dorsal half of the eye is pigmented. The cuticle is ridged in appearance, the heart beats normally, and the legs twitch spasmodically. The yolk has been completely enclosed by the midgut by $55 \%$ embryogenesis, and Malpighian tubules are formed. In the CNS, interganglionic connectives are formed. At $70 \%$ embryogenesis, the secondary cuticle is apolysed from the underlying epidermis. The Malpighian tubules are mobile and contain a yellow fluid.

By $80 \%$, the eyes are heavily pigmented, although the two most ventral rows of facets are only outlined by pigment. Faint pigmentation is observed at the base of the antennae. Bristles form at this stage. The gut becomes mobile and filled with yellow fluid; hepatic caecae develop. The CNS ganglia are similar in appearance to those in the first instar. By $90 \%$ embryogenesis, the eyes, mandible teeth, and bristles are fully pigmented. Brief muscle twitches and slow peristaltic contractions are noted occasionally. At 95\%, opening the ootheca may be followed by a hatching reaction, but only after a long interval. Finally, at $100 \%$ embryogenesis, most individuals are competent to hatch; peristaltic body contractions and air-swallowing result in emergence from the ootheca and simultaneous first ecdysis.

Development of giant interneurone 2. Using Nomarski optics, the cell body of $\mathrm{Gl} 2$ can be identified by its characteristic size, position, and appearance. The soma in the first instar is $26 \pm 1$ (SE) $\mu \mathrm{m}$ in diameter, situated just posterior and dorsal to nerve 8 and its associated tracheal trunk. The cytoplasmic volume is greater than in surrounding neurones and has a distinclive granular appearance. The nucleolus is also conspicuous. The branching pattern of Gl 2 at hatching (Fig. 2) is very similar to that of the adult cell (Fig. 2) described by Harrow et al. (1980) and Daley et al. (1981). The primary neurite projects from the cell body to the center of the contralateral neuropile, where it divides and gives rise to an anteriorly directed axon and a posteriorly directed dendrite. The axon extends as far as the brain and forms small medial branches in each abdominal ganglion. The main dendrite arborizes in a region of neuropile enclosed by branches of first instar cercal sensory axons (Blagburn and Beadle, 1982) which resembles the cercal glomerulus described in the grasshopper (Shankland, 1981b; Shankland and Goodman, 1982). The axon, neurite, and primary dendrite give rise to secondary dendrites in this region, and these branch profusely, forming an ovoid region of dendritic processes. Two other areas of dendrite arborization can be seen; the first arises from the neurite in the neuropile ipsilateral to the cell body and the second extends from the axon in the medial region of the anterior neuropile.

In early embryonic stages $(<45 \%)$, the cell body of Gl 2 is more difficult to identify, since it is embedded in a cluster of similar cells. Its position is the most reliable criterion for identification, with the soma located between nerves 8 and 9 near the anterior of a cluster of similar cells, directly adjacent to the anterior commissure of ganglion rudiment 9 . Gl 2 is two cell layers below the dorsal surface and from the lateral edge of the ganglion, with an anterior neighboring cell body of similar diameter. At $45 \%$ embryogenesis (Fig. 2), the ganglion rudiment $A_{7}$ is not yet completely fused to the terminal ganglion, the axon of Gl 2 extends into the anterior ganglion rudiments, and the primary dendrite is present. The neurite, axon, and dendrite bear fine processes which are almost certainly filopodia. These are particularly long and abundant in areas where branching will eventually be observed, such as the neurite in the medial ipsilateral neuropile and the axon in the neuropile of ganglion rudiment $A_{7}$. By $55 \%$ (Fig. 2), at least six secondary dendrite branches are formed. These have swollen ends bearing filopodia and resem- 

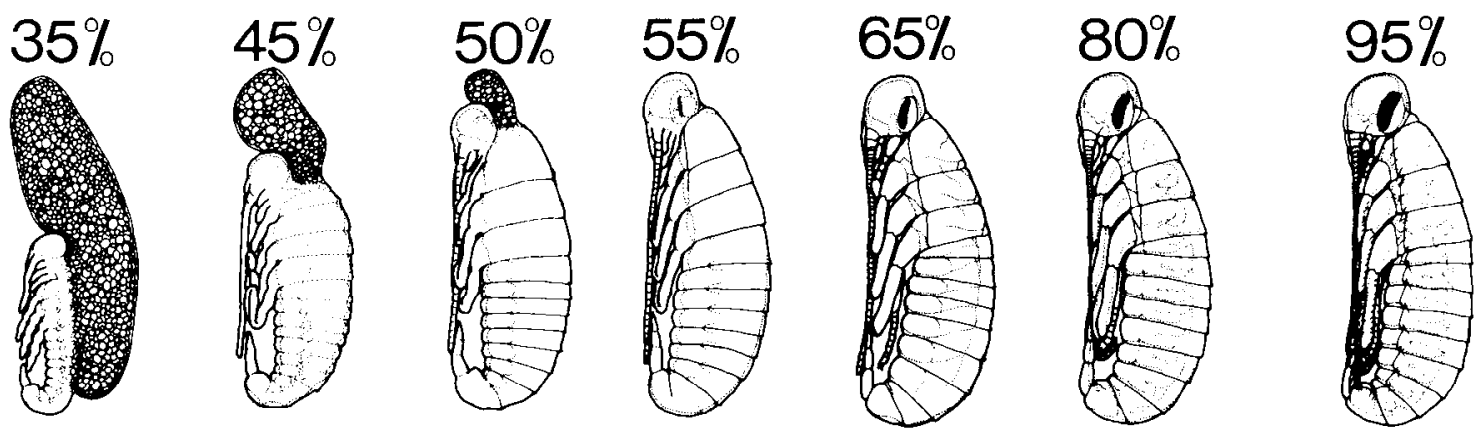

Figure 1. Embryogenesis of Periplaneta americana. Lateral view of embryos at various percentage stages throughout development. The scale bar represents $1 \mathrm{~mm}$.

bling growth cones. The anterior collateral axon branch is also initiated at this time. A sequential proliferation of branches is observed from this stage until $80 \%$ (Fig. 2), by which time the characteristic branching pattern of the mature cell is established.

Postembryonic changes in Gl 2 appear to be confined to an increase in the size of the cell and an increase in the number of dendritic branches. Different regions of the neurone have different growth rates, with the cell body being proportionally smaller and the axon proportionally larger in the adult (Fig. 2). Similarly, the portion of the terminal ganglion occupied by the arborization of the adult cell is smaller, probably due to the massive postembryonic ingrowth of cercal afferent axons.

Electrical properties of giant interneurone 2 during development The recorded resting potential of Gl 2 increases significantly from $-58 \pm 2 \mathrm{mV}$ in the 35 to $42 \%$ period of embryogenesis to $-71 \pm$ $1 \mathrm{mV}$ during the 80 to $85 \%$ stages. There is a subsequent significant increase to $-77 \pm 1 \mathrm{mV}$ in the first instar, and we have detected no further postembryonic change (Table $\mid$ ). The $R_{\text {in }}$ increases from 23 \pm 5 megohms at 35 to $42 \%$ embryogenesis to $43 \pm 6$ megohms at 51 to $53 \%$. There is a subsequent decrease to $20 \pm 2$ megohms in the first instar. For the adult cell, values for $R_{i n}$ of 3 to 4 megohms are obtained. Some degree of membrane rectification was observed after the 60 to $65 \%$ stage (Fig. 3).

Action potentials were not observed in Gl 2 before $55 \%$ embryogenesis. After this stage, nonovershooting action potentials (amplitude, 10 to $20 \mathrm{mV}$ ) were recorded from the cell body. Short bursts of spikes were elicited by suprathroshold (approximatcly $20 \mathrm{mV}$ ) depolarizations which follow the application of carbamylcholine to the dendrites. After $75 \%$ embryogenesis, many cells exhibited continuous spike activity for long periods, while others produced spontaneous depolarizing potentials of varying amplitude ( 1 to $10 \mathrm{mV}$; Fig. 3).

Chemosensitivity of giant interneurone 2 during development. Ionophoretic application of carbamylcholine to the soma and to the dendrites of Gl 2 resulted in transient depolarization of the cell membrane, the amplitude of which was dependent upon the dose (Fig. 4). Application of the agonist to either region of $\mathrm{Gl} 2$ at the 35 to $42 \%$ stage of embryogenesis elicited no measurable response. A dose of $1 \mathrm{nC}$ to the dendrites of $\mathrm{Gl} 2$ in the first instar elicited a response of $1 \mathrm{mV}$ with a very short latency and a duration of approximately $200 \mathrm{msec}$. The time taken to reach the peak of the response was $50 \mathrm{msec}$. Rise times were consistent with the agonist acting close to the site of application. The maximum depolarization amplitude $\left(\Delta V_{\max }\right)$ ranged from $+20 \mathrm{mV}$ at the $50 \%$ stage to +44 $\mathrm{mV}$ at $85 \%$.

The minimum dose $(Q)$ of agonist required to produce a response of $1 \mathrm{mV}$ amplitude can be estimated by the equation $Q=(1 / F) \mathrm{CH}$, where $Q=$ amount of substance released (moles); $F=$ the Faraday ( 96,400 coulombs/equivalent); $C=$ coulombs passed; and $H=$ the transport number $(0.1$ for acetylcholine, after Dionne, 1976). The value of $Q$ for the dendrites drops from $2 \times 10^{-14} \mathrm{~mol}$ at $50 \%$ embryogenesis to $1 \times 10^{-16}$ after $65 \%$. The value of $Q$ for the cell body varies from $2 \times 10^{-14} \mathrm{~mol}$ at 80 to $85 \%$ to $2 \times 10^{-13} \mathrm{~mol}$ at 60 to $65 \%$; the value for the first instar cell body is $1 \times 10^{-14} \mathrm{~mol}$ and that for the adult is $5 \times 10^{-14} \mathrm{~mol}$. This compares with the value of $2.5 \times 10^{-15} \mathrm{~mol}$ obtained for the application of ACh to the cell body in the presence of $1.0 \times 10^{-6} \mathrm{M}$ neostigmine (Harrow and Saltelle, 1983), suggesting that carbamylcholine is 20 times less effective an agonist than ACh. Similarly, the value for $Q$ obtained for the dendrites of $\mathrm{Gl} 2$ in the first instar $\left(1 \times 10^{-15} \mathrm{~mol}\right)$ is greater than that for the dendrites of the adult $\mathrm{Gl} 1\left(3 \times 10^{-17}\right.$ mol of $\mathrm{ACh}$; Callec et al., 1982), although this may also be due to differences in sensitivity between Gl 1 and Gl 2 and/or postembryonic changes.

The log-dose response curves (Fig. 5) for dendritic application of carbamylcholine to the later embryonic and first instar neurone show that maximal responses $\left(\Delta V_{\max } 30\right.$ to $45 \mathrm{mV}$ ) are elicited by doses of 10 to $50 \mathrm{nC}$. The maximum sensitivity of $\mathrm{Gl} 2$ dendrites at the $50 \%$ stage is $0.14 \pm 0.04 \mathrm{mV} / \mathrm{nC}$. This increases to $4.0 \mathrm{mV} / \mathrm{nC}$ at $55 \%$ and subsequently to $9.1 \pm 2.4 \mathrm{mV} / \mathrm{nC}$ at 60 to $65 \%$, from which value it does not deviate significantly until hatching (Table II).

However, analysis of data for the dendrites of Gl 2 is complicated by the cable properties of the neurite. Its small radius and many fine branches are likely to reduce the length constant, resulting in attenuation of the responses to a significant degree. It can be estimated that attenuation would be insignificant if the specific membrane resistance $\left(R_{m}\right)$ of the neurite were ten times the value in the cell body. Thus, although it is not possible to give accurate values of dendrite chemosensitivity, the pattern of relative develop mental changes can be discerned.

The maximum sensitivity of the soma decreased from $0.1 \pm 0.05$ $\mathrm{mV} / \mathrm{nC}$ at $52 \%$ to $0.01 \pm 0.002 \mathrm{mV} / \mathrm{nC}$ at 60 to $65 \%$ embryogenesis. The first instar neurone has the same sensitivity, $0.014 \pm 0.005 \mathrm{mV} /$ $\mathrm{nC}$, but at $80 / 85 \%$, the value is $0.07 \pm 0.02 \mathrm{mV} / \mathrm{nC}$. In the adult, the maximum sensitivity is $0.05 \pm 0.01 \mathrm{mV} / \mathrm{nC}$. The $\Delta V_{\max }$ for the cell body exhibits no significant changes, remaining within the range of 25 to $42 \mathrm{mV}$ throughout development. The mean value is $31 \pm 2$ $\mathrm{mV}$. These maximal responses are elicited by doses of 2,000 to $20,000 \mathrm{nC}$

The injection into the soma of $0.3 \mathrm{nA}$ depolarizing current pulses of $250 \mathrm{msec}$ duration at a frequency of $2 \mathrm{~Hz}$ before and during drug application allows a direct measurement of $R_{\text {in }}$ and conductance change $(\Delta g)$ to be made (Fig. 4$)$. For small ( $\leq 10 \mathrm{mV}$ ) responses the reversal potential $(\mathrm{Vr})$ can be estimated as $-40 \mathrm{mV}$ from

$$
\Delta g=\frac{\Delta V}{R(E-\Delta V)}
$$

where $\Delta V=$ voltage change, $R=$ input resistance, and $E=V r-$ resting potential. Since current pulses into the cell body cannot be used to measure $\Delta g$ in the dendrites, it is not known if $V r$ is the same for the dendrites as for the cell body. For this reason, $\Delta g_{\max }$ cannot be calculated for the dendrite responses, and only the pattern 


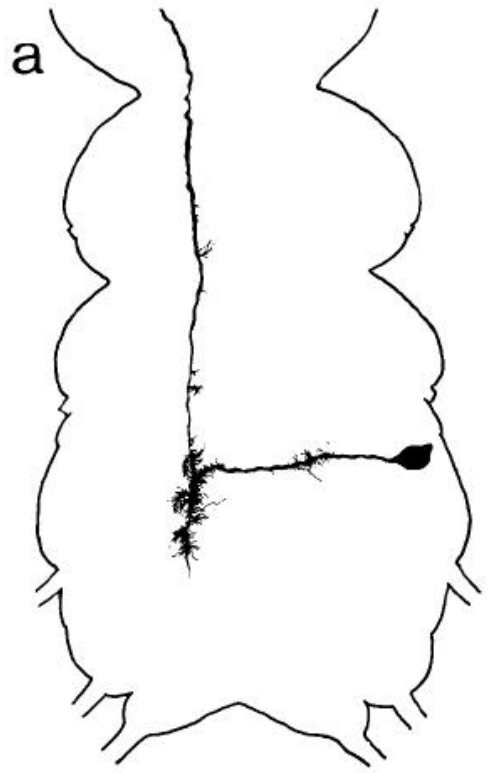

b

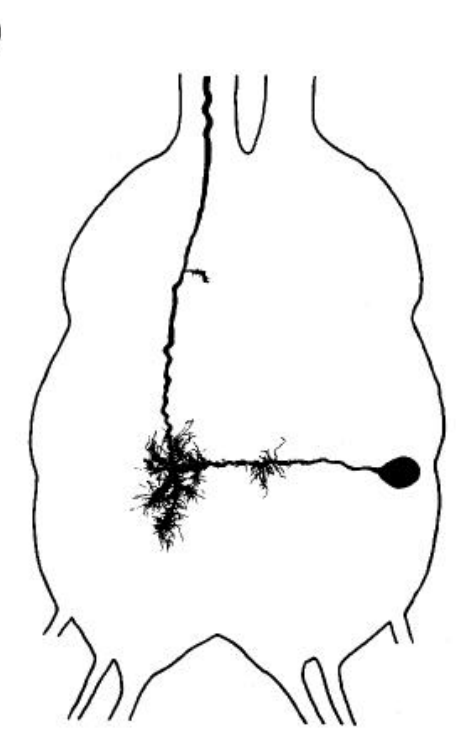

d
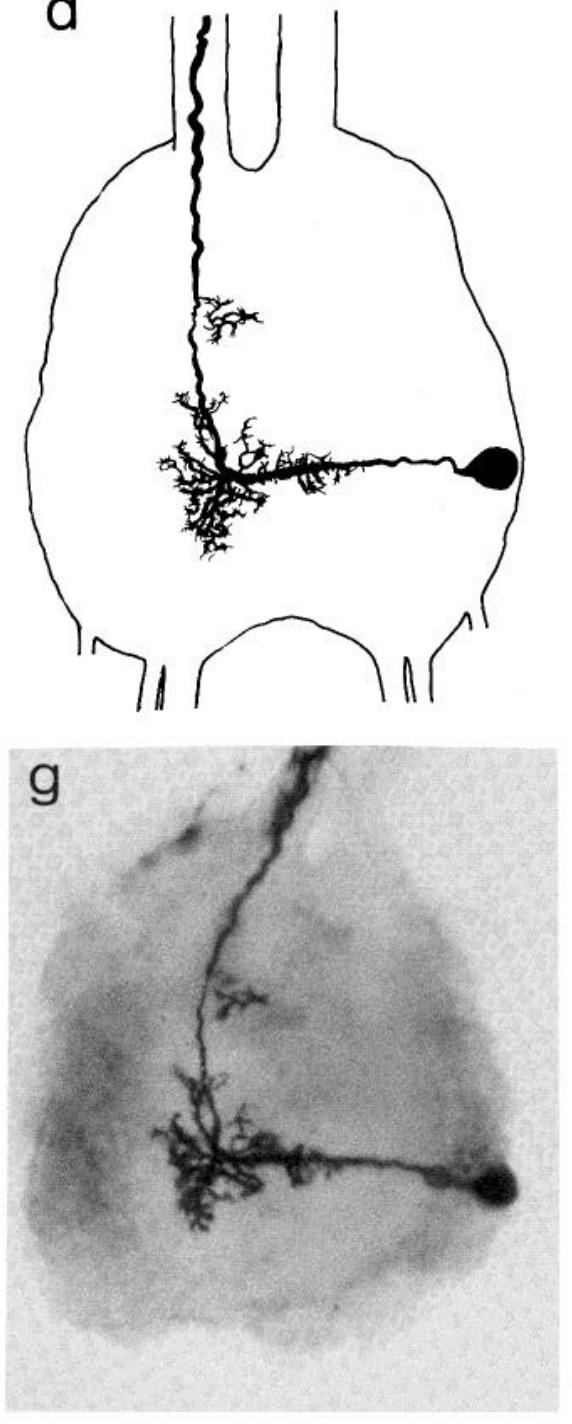

C
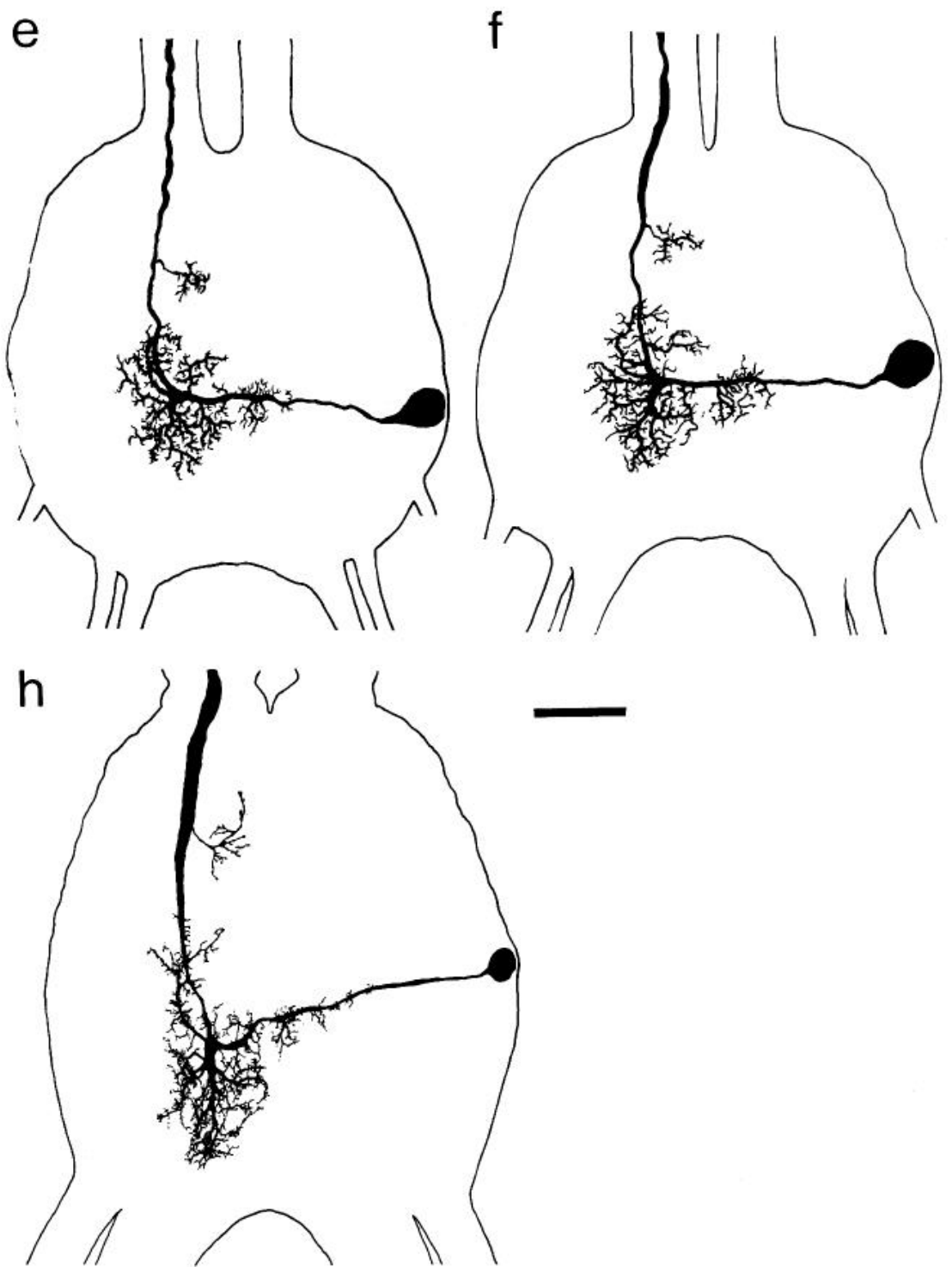

Figure 2. Development of $\mathrm{Gl}$ 2. Camerica lucida tracings were made of whole mounts of cobalt-injected, silver-intensified neurones at various stages of embryonic and postembryonic development. $a, 45 \%$ of embryogenesis; $b, 55 \% ; c, 65 \% ; d, 75 \% ; e, 80 \% ; f$, first instar; $h$, adult; $g$ is a photomicrograph of the $75 \%$ neurone represented in $d$. The scale bar represents $50 \mu \mathrm{m}$ for a to $g$ and $150 \mu \mathrm{m}$ for $h$. Filopodia are present on dendritic branches up to $75 \%$. At $80 \%$, the branching pattern is complete. 
TABLE I

Properties of giant interneurone 2 throughout development

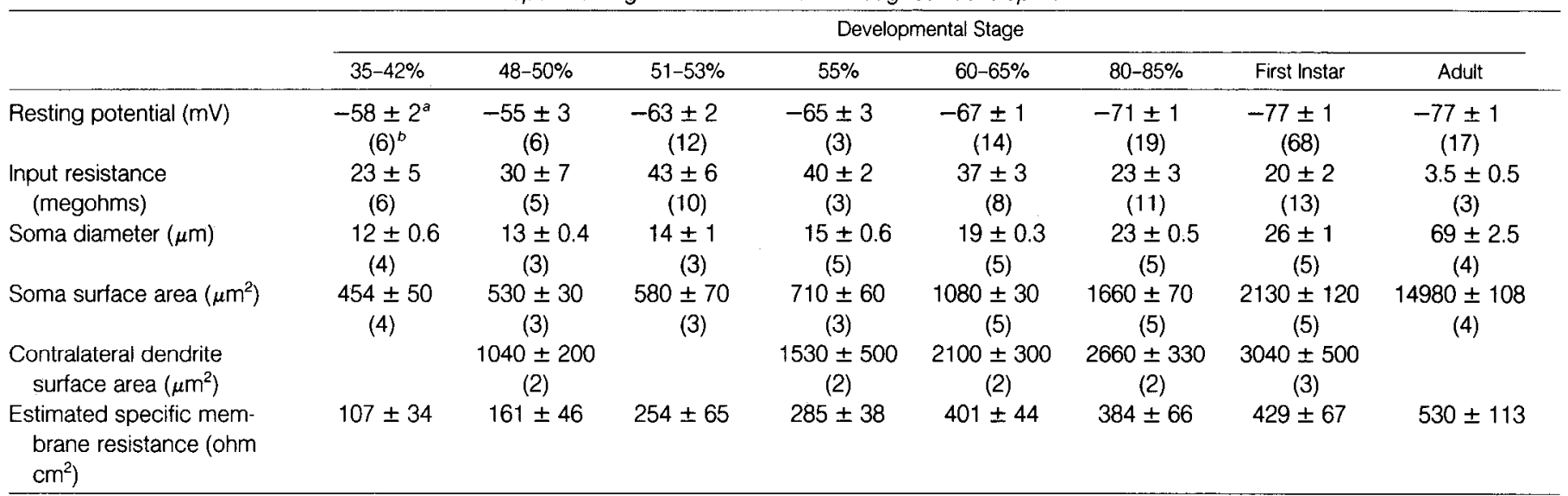

${ }^{a}$ Mean \pm SE.

${ }^{b}$ Numbers in parentheses, number of experiments.
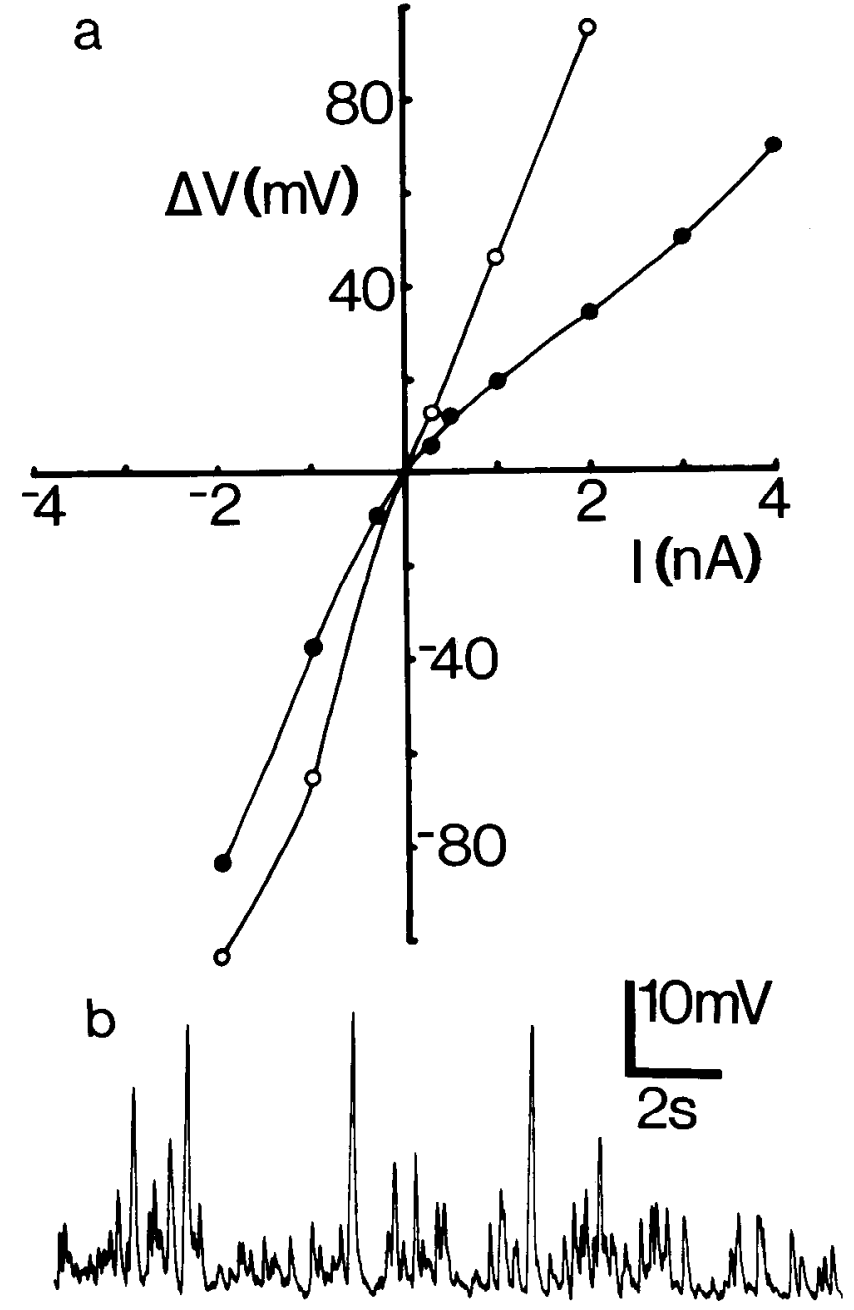

Figure 3. Electrical properties of $\mathrm{Gl} 2$ 2. a, IN curves for $\mathrm{Gl} 2$ at $51 \%$ embryogenesis (open circles) and in the first instar (solid circles). Each curve represents the mean of 4 neurons at each age. $b$, Spontaneous action potentials and possible synaptic activity, recorded from the soma of the first instar Gl 2.

of relative changes in chemosensitivity can be discerned. Similarly, it is not possible to determine if the dendrites undergo greater or lesser changes in conductance than the cell body. Hill plots were

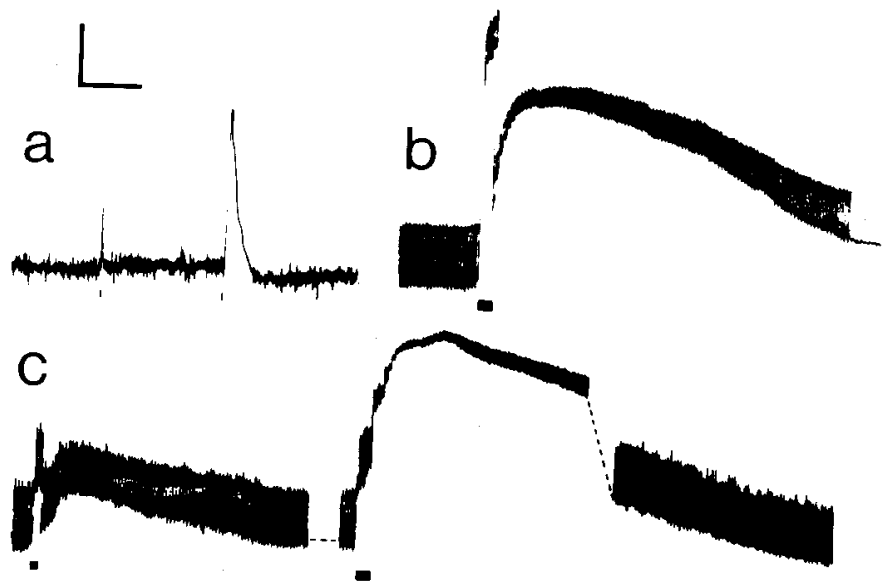

Figure 4. Intracellularly recorded responses of GI 2 to carbamylcholine. a, Applications $(0.2 \mathrm{sec})$ of drug ( 4 and $12 \mathrm{nC}$, respectively) to the center of the contralateral dendritic field of first instar Gl 2. Resting potential, $-78 \mathrm{mV}$. b. Application (2 sec) of carbamylcholine $(9,000 \mathrm{nC}$ ) to the soma of $\mathrm{Gl} 2$ at the $61 \%$ stage of embryogenesis. Depolarizing $0.3 \mathrm{nA}$ pulses were applied throughout the response. Resting potential, $-67 \mathrm{mV}, c, 1 \mathrm{~s}(2,000 \mathrm{nC})$ dose applied to the soma of first instar Gl 2. Resting potential, $-81 \mathrm{mV}$; calculated $V_{r 1}-44 \mathrm{mV}$. After $2 \mathrm{~min}$, a 2-sec $(12,000 \mathrm{nC})$ dose was applied. Depolarizing 0.3-nA pulses were applied throughout the responses. A 35-sec period has been removed from the latter part of the record. Vertical scale, $10 \mathrm{mV}$; horizontal scale, $10 \mathrm{sec}$.

constructed using the values of $\Delta \mathrm{g}$ obtained for the cell body at the stages shown in Table II. Values obtained for the Hill coefficient $\left(n_{H}\right)$ approximated to 1.5 , and no significant change was seen at any stage.

The surface area of the soma and of the contralateral dendrites can be estimated from the dimensions of the cells filled with cobalt. It is assumed that cobalt penetrates all the finest branches of the neurone and that all branches are circular in cross-section. Preliminary low-power electron-microscopical observations (J. M. Blagburn, D. J. Beadle, and D. B. Sattelle, unpublished observations) yield similar values for the dimensions of branches in horseradish peroxidase fills. The calculated area of the soma in later stages is likely to be a slight underestimate because of the ingrowth of glial trophospongia. In the case of the dendrites, the number of processes of a certain diameter can be ascertained and, hence, value for the dendritic surface area can be estimated (Table I).

\section{Discussion}

The branching pattern of giant interneurone 2 in the sixth abdominal ganglion of $P$. americana is described, based on intracellular 

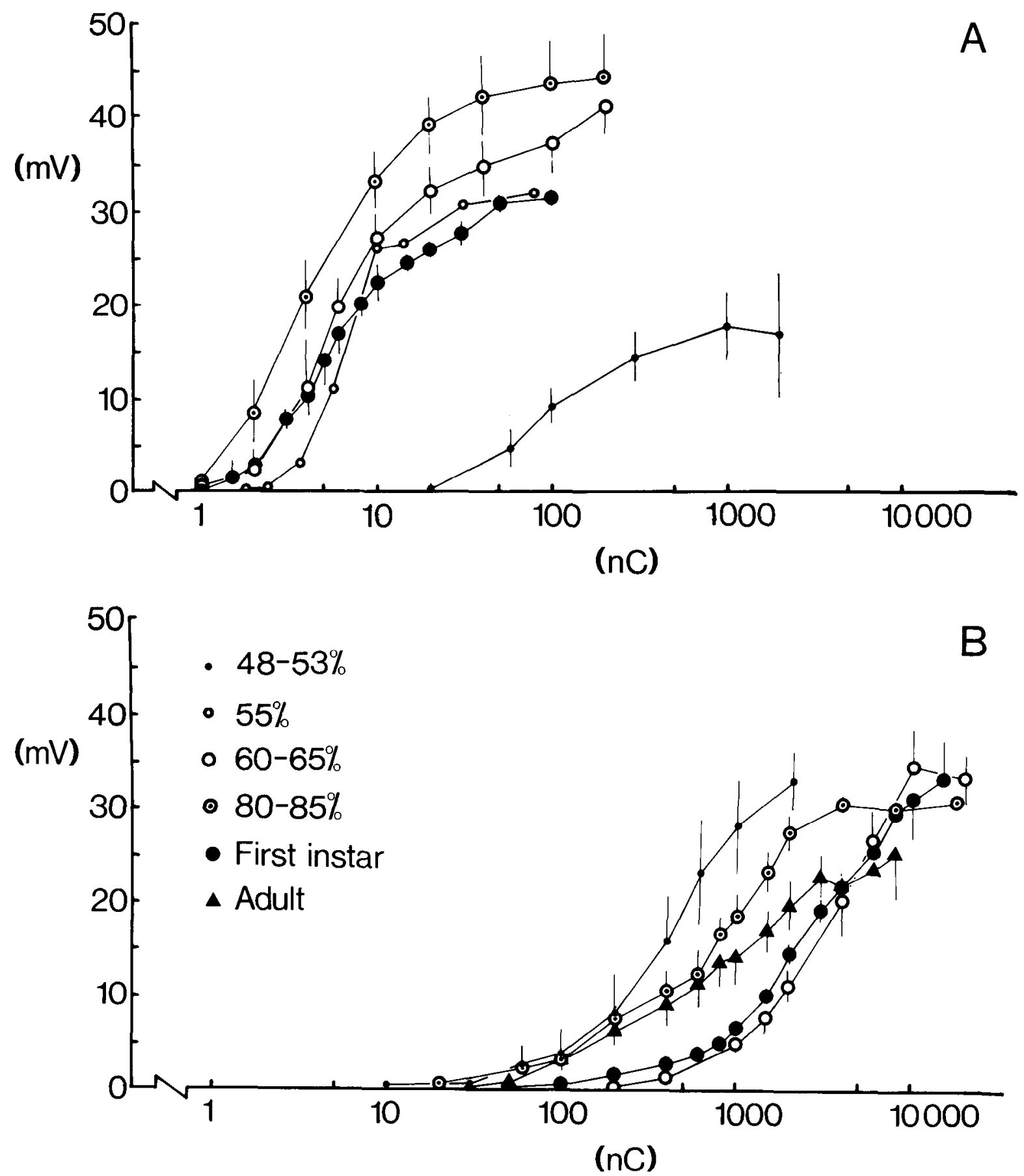

Figure 5. Dose-response curves for ionophoretic application of carbamylcholine to $\mathrm{Gl}$ 2. The resultant depolarization (mV) is plotted against the ionophoretic charge applied (nC), for various developmental stages. A, Application of carbamylcholine to the centre of the contralateral dendritic field of Gl 2. $B$, Application of the agonist to the cell body membrane. Vertical bars represent SE.

cobalt fills performed at a series of embryonic stages. The neurone undergoes a sequential proliferation of dendrite branches between the $45 \%$ and the $80 \%$ stages of embryogenesis, resulting in a miniature version of the morphology of the adult cell. Growth of branches is preceded by the appearance of transient filopodia, and apparently no inappropriate branches are formed during this period. The morphology and the developmental timetable of this neurone closely resemble those of the medial giant interneurone (MGl) in $S$. americana (Shankland and Goodman, 1982). In both neurones, there is a well-defined region of dendrites contralateral to the cell body and an ipsilateral region of small branches on the neurite. However, in $\mathrm{MGl}$, the contralateral dendrites give rise to branches which cross the midline of the ganglion, but in Gl 2, such branches are not detected. Gl 2 forms a small axonal branch in the region of neuropile formed from ganglion rudiment $A_{7}$; in Schistocerca, $A_{7}$ does not fuse with the terminal ganglion, and this branch is absent. The common origin of the cells in ganglion rudiment $A_{9}$ suggests that there may be some degree of interspecific homology between the cockroach Gl 2 and the grasshopper MGl.

The recorded resting potential of $\mathrm{Gl} 2$ increases throughout the last half of embryogenesis, from -58 to $-77 \mathrm{mV}$. No subsequent postembryonic change in resting potential was noted. The input resistance of the cell increases from 35 to $40 \%$ embryogenesis to $60 \%$ then decreases until hatching. A further postembryonic decrease in $R_{\text {in }}$ takes place. Estimates of the specific membrane resistance $\left(R_{m}\right)$ suggest that this property increases from the 35 to 
TABLE ॥

Chemosensitivity of giant interneurone 2 throughout development

\begin{tabular}{|c|c|c|c|c|c|c|c|c|}
\hline & \multicolumn{8}{|c|}{ Developmental Stage } \\
\hline & $35-42 \%$ & $48-50 \%$ & $51-53 \%$ & $55 \%$ & $60-65 \%$ & $80-85 \%$ & First Instar & Adult \\
\hline \multicolumn{9}{|c|}{$\begin{array}{l}\text { Maximum sensitivity } \\
\qquad\left(\mathrm{mV} n \mathrm{C}^{-1}\right)\end{array}$} \\
\hline Soma & $\begin{array}{l}0 \\
(3)^{a}\end{array}$ & $-^{b}$ & $\begin{array}{c}0.098 \pm 0.051^{\circ} \\
(5)\end{array}$ & - & $\begin{array}{c}0.010 \pm 0.002 \\
(9)\end{array}$ & $\begin{array}{c}0.067 \pm 0.002 \\
(6)\end{array}$ & $\begin{array}{c}0.014 \pm 0.005 \\
\text { (4) }\end{array}$ & $0.047 \pm 0.0014$ \\
\hline Dendrites & $\begin{array}{c}0 \\
(1)\end{array}$ & $\begin{array}{c}0.14 \pm 0.04 \\
(3)\end{array}$ & - & $\begin{array}{l}4.0 \\
(1)\end{array}$ & $\begin{array}{c}9.1 \pm 2.4 \\
(4)\end{array}$ & $\begin{array}{c}10.9 \pm 4.9 \\
(3)\end{array}$ & $\begin{array}{c}5.6 \pm 0.8 \\
(3)\end{array}$ & - \\
\hline Soma & - & - & $\begin{array}{c}144 \pm 52 \\
(10)\end{array}$ & - & $\begin{array}{c}98 \pm 21 \\
(9)\end{array}$ & $\begin{array}{c}127 \pm 20 \\
(9)\end{array}$ & $\begin{array}{c}249 \pm 42 \\
(11)\end{array}$ & $\begin{array}{c}920 \pm 260 \\
(8)\end{array}$ \\
\hline \multicolumn{9}{|c|}{ Apparent $K_{50}(n C)$} \\
\hline Soma & - & - & $\begin{array}{c}1440 \pm 830 \\
(5)\end{array}$ & - & $\begin{array}{c}6090 \pm 1350 \\
(9)\end{array}$ & $\begin{array}{c}1670 \pm 460 \\
(6)\end{array}$ & $\begin{array}{c}6400 \pm 900 \\
\text { (4) }\end{array}$ & $\begin{array}{c}3760 \pm 990 \\
(8)\end{array}$ \\
\hline
\end{tabular}

${ }^{a}$ Numbers in parentheses, number of experiments.

${ }^{b} \mathrm{Bar}$, not tested.

${ }^{\circ}$ Mean $\pm \mathrm{SE}$.

$42 \%$ stage up to approximately $60 \%$ embryogenesis and then remains constant. The apparent initial increase in $\mathrm{R}_{\mathrm{m}}$ is probably due to progressive electrical uncoupling of $\mathrm{Gl} 2$ from its neighboring cells. The true value of $R_{m}$ at this time is probably $\sim 400 \mathrm{ohm} \mathrm{cm}^{2}$. A similar embryonic increase in $R_{m}$ appears to take place in grasshopper DUM neurones where the oldest progeny of the DUM neuroblast become uncoupled at $55 \%$ embryogenesis (Goodman and Spitzer, 1981). Electrical excitability appears by $55 \%$, and spontaneous depolarizing potentials of varying amplitude probably representing synaptic input are present by $75 \%$. This sequence of events is approximately equivalent to that in MGI and DUMeti (Goodman and Spitzer, 1981; Shankland and Goodman, 1982).

Carbamylcholine has proved to be a potent ligand at the insect ACh receptor characterized by $\left[{ }^{125} \mid\right] \alpha$-bungarotoxin binding (Schmidt-Nielsen et al., 1977; Sattelle, 1980). It has also been shown to be a potent agonist at ACh receptors that participate in transmission at the cercal afferent, Gl synapses (Sattelle et al., 1976; Sattelle, 1.978 ) which are blocked by nanomolar concentrations of $\alpha$-bungarotoxin (Harrow et al., 1979; Sattelle et al., 1980; 1983; Harrow et al., 1982). In addition, carbamylcholine is not hydrolyzed by cholinesterase (Koelle, 1975), which is present in the neuropile of the terminal ganglion from $55 \%$ (Blagburn, unpublished observation).

Throughout the development of Gl 2, a general pattern of changes in chemosensitivity can be discerned. Sensitivity to carbamylcholine first appears at approximately 40 to $45 \%$ embryogenesis to a similar degree over the whole cell. In Gl 2, the carbamylcholine sensitivities of the dendrites and soma rapidly diverge in value, with that of the dendrites increasing at least 100 -fold and that of the soma decreasing 10 -fold by 60 to $65 \%$ embryogenesis.

During late embryogenesis (near $80 \%$ ), there is apparently a peak in cell body and dendritic chemosensitivity. In both regions of the cell, there is a subsequent decline in sensitivity prior to hatching. In the first instar, the dendrites are 500 to 1000 times more sensitive to carbamylcholine than the cell body. During postembryonic development, the soma sensitivity triples. It is not known whether this increase also takes place in the dendrites.

Chemosensitivity in DUMeti appears at a similar stage in development in all regions of the cell and decreases slightly after synaptic input appears at $75 \%$ embryogenesis, although this may be due to a decrease in input resistance (Goodman and Spitzer, 1980). A similar rise in receptor numbers before and during synaptogenesis has been detected in the antennal lobes of $M$. sexta (Sanes et al.,
1977) and in the chick retina (Vogel and Nirenberg, 1976). A subsequent decline in $\alpha$-bungarotoxin binding activity has been detected in the chick ciliary ganglion which has been related to synaptic maturation (Wang and Schmidt, 1976).

It is interesting to note that the difference in chemosensitivity between the dendrites and the soma is 500- to 1000-fold. A large proportion of the dendritic membrane is probably postsynaptic, whereas no synapses have been reported to occur on adult insect neuronal cell bodies (Smith and Treherne, 1965). In comparison, the ACh sensitivity of synaptic regions of frog parasympathetic ganglion cell bodies is $276 \mathrm{mV} / \mathrm{nC}$, whereas that of extrasynaptic regions is no more than $164 \mathrm{mV} / \mathrm{nC}$ (Harris et al., 1971). At the vertebrate neuromuscular junction, the sensitivity of the postsynaptic surface ranges from 1500 to $8000 \mathrm{mV} / \mathrm{nC}$ (Fambrough, 1979); in the rat diaphragm, extrasynaptic regions are 1000 times less sensitive than the end-plate (Miledi, 1960), whereas in snake muscle there is a difference of only 50-fold (Kuffler and Yoshikami, 1975).

The maximum slope of the dose-response curve has been used as a measure of chemosensitivity (Harris et al., 1971; Kuffler and Yoshikami, 1975), and this is thought to be proportional to the square of the receptor density (Hartzell and Fambrough, 1972). Changes in the shape of the curve have thus been attributed to changes in receptor density. The present results can be interpreted in this way, in which case the changes in the maximum slope of the dose-response curves suggest that large changes in both soma and dendrite receptor density take place as the neurone develops.

However, Dreyer et al. (1978) have shown that a dose-response curve can be described by at least three parameters: $n_{H}$ (the Hill coefficient); $\Delta g_{\max }$ (the maximum conductance change, proportional to the receptor density); and $\mathrm{K}_{50}$ (apparent affinity constant, equivalent to the dose at which a response of $\Delta g_{\max } / 2$ is elicited). In the present study, $\mathrm{n}_{\mathrm{H}}$ for the cell body responses is approximately 1.5 at all the stages investigated; thus the maximum slope of the curves is determined by $\Delta g_{\max }$ and $\mathrm{K}_{50}$. If $\Delta g_{\max }$ is a measure of the receptor density, there is little significant variation in $\Delta g_{\max }$ and receptor density throughout embryogenesis until the period between $85 \%$ and the first instar in which $\Delta g_{\max }$ approximately doubles. This change may take place in the last part of embryonic development or in the posthatching period, when the giant interneurones become behaviorally functional. A further 3- or 4-fold increase takes place during postembryonic development.

Comparison of the $\mathrm{K}_{50}$ values (Table II) apparently shows that the 
values at the soma differ at 51 to $53 \%$ and 80 to $85 \%$ from those at 60 to $65 \%$ and the first instar. These relatively small variations could be caused by differing degrees of glial investment remaining around the cell bodies. On the other hand, glial layers develop progressively, around the neuronal somata during embryogenesis and postembryonic development (J.M. Blagburn, unpublished observation), whereas there is no such age-dependent shift in cell body $K_{50}$ values.

In addition, there are apparenlly 200- to 500-fold differences between the soma $K_{50}$ and those estimated for the dendrites. Large shifts in the apparent value of $K_{50}$ can be produced by the removal of a "receptor reserve" using an irreversible antagonist (Triggle and Triggle, 1976). Carbamylcholine is a strong agonist, and the total number of receptors in the dendrites may be in excess of that required to produce a maximal response. At the soma, this excess may be absent, resulting in the same maximal response but giving a higher value for the $\mathrm{K}_{50}$. The possibility exists that access of carbamylcholine to the cell body membrane may be restricted by glial layers remaining around the soma after desheathing, whereas access to dendritic membranes is relatively unrestricted. The difference in time course of the responses recorded from the two regions of the neurone may support this idea. Alternatively, the values of $\Delta g_{\text {max }}$ for the dendrites may be orders of magnitude greater than those measured during the cell body responses; in this casc, the values of $\mathrm{K}_{50}$ may not in fact be significantly different.

In Gl 2, there is a rapid divergence in the chemosensitivities of synaptic areas (represented by the dendrites) and extrasynaptic areas (represented by the cell body). This divergence takes place by $55 \%$ embryogencsis, at which stage only the primary dendrite branches and numerous filopodia are present and morphologically mature synaptic contacts have not formed (Blagburn et al., 1985). It seems that any mechanism by which receptors are preferentially localized in dendritic membranes must be initiated before the onset of synapse formation, perhaps by transient filopodial contact. In Manduca, clustering of receptors in synaptic areas of the antennal lobe takes place even in the absence of afferent antennal innervation (Hildebrand et al., 1979), although the possible influence of nonantennal neurones cannot be ruled out. In contrast, during the in vivo development of neuromuscular junctions, ACh receptor clusters only form on myotubes after innervation and do not occur in extrajunctional areas (Bevan and Steinbach, 1977). In vitro ACh receptors cluster betore innervation, but there is no tendency for nerves to grow to preexisting clusters, and receptors subsequently accumulate at the newly formed synapses (Frank and Fischbach, 1977). The available evidence suggests that changes in receptor density in insect neurones take place before synapse formation, and a possible guiding role for receptor clusters cannot, as yet, be ruled out. Giant interneurone 2 in the terminal ganglion of $P$. americana emerges as a suitable candidate for development studies, since both synaptic and extrasynaptic regions of the cell are accessible to microionophoresis of receptor agonists.

\section{References}

Bacon, J. P. and J. S. Altman (1977) A silver-intensification method for cobaltfilled neurones in wholemount preparations. Brain. Res. 138: 359-363.

Bentley, D., H. Keshishian, M. Shankland, and A. Toroian-Raymond (1979) Quantitative staging of embryonic development of the grasshopper, Schistocerca nitens. J Embryol. Exp. Morphol. 54: 47-74.

Bevan, S. and J. H. Steinbach (1977) The distribution of $\alpha$-bungarotoxin binding sites on mammalian skeletal muscle developing in vivo. J. Physiol. (Lond.) 267: 195-213

Blagburn, J. M. and D. J. Beadle (1982) Morphology of identified cercal afferents and giant interneurones in the hatching cockroach, Periplaneta americana. J. Exp. Biol. 97: 421-426.

Blagburn, J. M., D. J. Beadle, and D. B. Sattelle (1984) Synapses between an identified giant interneurone and a filiform hair sensory neurone in the terminal ganglion of first instar cockroaches (Periplaneta americana L.) J. Exp. Biol. 113: 477-481.

Blagburn, J. M., D. J. Beadle, and D. B. Sattelle (1985) Development of synapses between identified sensory neurones and giant interneurones in the cockroach (Periplaneta americana L.) J. Embryol. Exp. Morphol. 86: 227-246.

Bugnion, E. (1921) The growth of the antennae and cerci of the cockroach, Periplaneta americana. Bull. Entomol. Soc. Egypt. Econ. Ser. 6: 56-66.

Callec, J. J. (1974) Synaptic transmission in the central nervous system of insects. In Insect Neurobiology, J. E. Treherne, ed., pp. 119-185, ElsevierNorth Holland, Amsterdam.

Callec, J. J. and D. B. Sattelle (1973) A simple technique for monitoring the synaptic actions of pharmacological agents. J. Exp. Biol. 59: 725-738.

Callec, J. J., D. B. Sattelle, B. Hue, and M. Pelhate (1980) Central synaptic actions of pharmacological agents in insects. In Insect Neurobiology and Pesticide Action, pp. 93-100. Society of Chemical Industry, London.

Callec, J. J., J. A. David, and D. B. Sattelle (1982) lonophoretic application of acetylcholine on to the dendrites of an identified giant interneurone (Gl 1) in the cockroach Periplaneta americana. J. Insect Physiol. 28: 10031008.

Camhi, J. M., W. Tom, and S. Volman (1978) The escape behaviour of the cockroach Periplaneta americana. II. Detection of natural predators by air displacement. J. Comp. Physiol. 128: 203-212.

Changeux, J. P. and A. Danchin (1977) Biochemical models for the selective stabilization of developing synapses. In Synapses, G. A. Cottrell and P. N. R. Usherwood, eds., pp. 239-248, Blackie, Glasgow.

Dagan, D. and S. Volman (1982) Sensory basis for directional wind detection in first instar cockroaches, Periplaneta americana. J. Comp. Physiol. 147: $471-478$.

Daley, D. L., N. Vardi, B. Appignani, and J. M. Camhi (1981) Morphology of the giant interneurons and cercal nerve projections of the american cockroach. J. Comp. Neurol. 196: 41-52.

David, J. A. and R. M. Pitman (1982) The effects of axotomy upon the extrasynaptic acetylcholine sensitivity of an identified motoneurone in the cockroach Periplaneta americana. J. Exp. Biol. 98: 329-341.

David, J. A. and D. B. Sattelle (1984) Actions of cholinergic pharmacological agents on the cell body membrane of the fast coxal depressor motoneurone of the cockroach (Periplaneta americana). J. Exp. Biol. 108: 119136.

Dionne, V. (1976) Characterization of drug iontophoresis with a fast microassay technique. Biophys. J. 16: 705-717

Dreyer, F., K. Peper, and R. Sterz (1978) Determination of dose-response curves by quantitative ionophoresis at the frog neuromuscular junction. $\mathrm{J}$. Physiol. (Lond.) 281: 395-419.

Edwards, J. S., and J. Palka (1974) The cerci and abdominal giant fibres of the house cricket Acheta domesticus I. Anatomy and physiology of normal adults. Proc. R. Soc. Lond. (Biol.) 185: 83-103.

Fambrough, D. M. (1979) Control of acetylcholine receptors in skeletal muscle. Physiol. Rev. 59: 165-227.

Frank, E. and G. D. Fischbach (1977) ACh receptors accumulate at newly formed nerve-muscle synapses in vitro. In Cell and Tissue Interactions, $J$ W. Lash and M. M. Burger, eds., pp. 285-292, Raven Press, New York.

Freeman, J. A. (1977) Possible regulatory function of acetylcholine receptor in maintenance of retinotectal synapses. Nature 269: 218-222.

Goodman, C. S. and N. C. Spitzer (1979) Embryonic development of identified neurones: Differentiation from neuroblast to neurone. Nature 280: 208-214.

Goodman, C. S. and N. C. Spitzer (1980) Embryonic development of neurotransmitter receptors in grasshoppers. in Receptors for Neurotransmitters, Hormones, and Theromones in Insects, D. B. Sattelle, L. M. Hall, and J. G. Hildebrand, eds., pp. 195-207. Elsevier/North-Holland Biomedical Press, Amsterdam

Goodman, C. S. and N. C. Spitzer (1981) The development of electrical properties of identified neurones in grasshopper embryos. J. Physiol. (Lond.) 313: 385-403.

Goodman, C. S., M. O'Shea, R. McCaman, and N. C. Spitzer (1979) Embryonic development of identified neurons: Temporal pattern of morphological and biochemical differentiation. Science 204: 1219-1222.

Harris, A. J., S. W. Kuffler, and M. J. Dennis (1971).Differential chemosensitivity of synaptic and extrasynaptic areas on the neuronal surface membrane in parasympathetic neurons of the frog, tested by microapplication of acetylcholine. Proc. R. Soc. Lond. (Biol.) 177: 541-553.

Harrow, I. D. and D. B. Sattelle (1983) Acetylcholine receptors on the cell body membrane of giant interneurone 2 in the cockroach, Periplanela americana. J. Exp. Biol. 105: 339-350.

Harrow, I. D., B. Hue, M. Pelhate, and D. B. Sattelle (1979) $\alpha$-Bungarotoxin blocks excitatory postsynaptic potentials in an identified insect interneurone. J. Physiol. (Lond.) 295: 63-64P. 
Harrow, I. D., B. Hue, M. Pelhate, and D. B. Sattelle (1980) Cockroach giant interneurones stained by cobalt-backfilling of dissected axons. J. Exp. Biol. 84: 341-343.

Harrow, I. D., J. A. David, and D. B. Sattcllc (1982) Acetylcholine receptors of identified insect neurons. Ciba Found. Symp. 88: 12-31.

Hartzell, H. C. and D. M. Fambrough (1972) Acetylcholine receptors. Distribution and extrajunclional derisity in rat diaphragm after degeneration correlated with acetylcholine sensitivity. J. Gen. Physiol: 60: 248-262.

Hildebrand, J. G., L. M. Hall, and B. C. Osmond (1979) Distribution of binding sites for ${ }^{125}$-labeled $\alpha$-bungarotoxin in normal and deafferented antennal lobes of Manduca sexta. Proc. Natl. Acad. Sci. U. S. A. 76: 499-503.

Koelle, G. B. (1975) Parasympathomimetic agents. In The Pharmacological Basis of Therapeutics, L. S. Goodman and A. Gilman, eds., pp. 467-476, MacMillan, New York.

Kuffler, S. W. and D. Yoshikami (1975) The distribution of ACh sensitivity at the postsynaptic membrane of vertebrate skeletal twitch muscles: lontophoretic mapping in the micron range. J. Physiol. (Lond.) 244: 703-730.

Matsumoto, S. G. and R. K. Murphey (1977) The cercus-to-giant interneurone system of crickets. IV. Patterns of connectivity between receptors and the medial giant interneuron. J. Comp. Physiol. 119: 319-330.

Mendenhall, B., and R. K. Murphey (1974) The morphology of cricket giant interneurons. J. Neurobiol. 5: 565-580.

Miledi, R. (1960) Junctional and extrajunctional ACh receptors in skeletal muscle fibres. J. Physiol. (Lond.) 151: 24-30.

Murphey, R. K., S. E. Johnson, and D. S. Sakaguchi (1983) Anatomy and physiology of supernumerary cercal afferents in crickets: Implications for pattern formation. J. Neurosci. 3: 312-325.

Ritzmann, R. E. and J. M. Camhi (1978) Excitation of leg motorneurons by giant interneurons in the cockroach Periplancta americana. J. Comp. Physiol. 125: 305-316.

Roeder, K. D. (1948) Organization of the ascending giant fibre system in the cockroach Periplanela americana. J. Exp. Zool. 108: 243-261.

Roeder, K. D., L. Tozian, and E. A. Weiant (1960) Endogenous nerve activity and behaviour in the mantis and cockroach. J. Insect Physiol. 4: 45-62.

Sanes, J. R., D. J. Prescott, and J. G. Hildebrand (1977) Cholinergic neurochemical development of normal and deafferented antennal lobes during metamorphosis of the moth Manduca sexta. Brain Res 119: 389 402.

Sattelle, D. B. (1978) The insect central nervous system as a site of action of neurotoxicants. In Pesticide and Venom Neurotoxicity, D. L. Shankland, R. M. Hollingworth, and T. Smyth, Jr., eds., pp. 7-26, Plenum Press, New York.
Sattelle, D. B. (1980) Acetylcholine receptors of insects. Adv. Insect Physiol. 15: $215-315$.

Sattelle, D. B., A. S. McClay, R. J. Dowson, and J. J. Callec (1976) The pharmacology of an inscct ganglion: Actions of carbamylcholine and acetylcholine. J. Exp. Biol. 64: 13-23.

Sattelle, D. B., J. A. David, I. D. Harrow, and B. Hue (1980) Actions of $\alpha$ bungarotoxin on identified insect central neurones. In Receptors for $\mathrm{Neu}$ rotransmitters, Hormones, and Pheromones in Insects, D. B. Sattelle, L. M. Hall, and J. G. Hildebrand, eds., pp. 125-139, Elsevier/North Holland Biomedical Press, Amsterdam.

Sattelle, D. B., I. D. Harrow, B. Hue, M. Pelhate, J. I. Gepner, and L. M. Hall (1983) $\alpha$-Bungarotoxin blocks excitatory synaptic transmission between cercal sensory neurones and giant interneurone 2 of the cockroach Periplaneta americana. J. Exp. Biol. 107: 473-489.

Schmidt-Nielsen, B. K., J. I. Gepner, N. N. H. Teng, and L. M. Hall (1977) Characterization of an $\alpha$-bungarotoxin binding component from Drosophila melanogaster. J. Neurochem. 29: 1013-1029.

Shankland, M. (1981a) Development of a sensory afferent projection in the grasshopper embryo. I. Growth of peripheral pioneer axons within the CNS. J. Embryol. Exp. Morphol. 64: 169-185.

Shankland, M. (1981b) Development of a sensory afferent projection in the grasshopper embryo. II. Growth and branching of peripheral pioneer axons within the CNS. J. Embryol. Exp. Morphol. 64: 187-209.

Shankland, M. and C. S. Goodman (1982) I. Development of the dendritic branching patterns of the medial giant interneuron in the grasshopper embryo. Dev. Biol. 92: 489-506.

Shankland, D. L., J. A. Rose, and C. Donniger (1971) The cholinergic nature of the cercal nerve-giant fibre synapse in the sixth abdominal ganglion of the American cockroach Periplaneta americana (L.) J. Neurobiol. 2: 247262

Smith, D. S. and J. E. Treherne (1965) The electron microscopic localization of cholinesterase activity in the central nervous system of an insect Periplaneta americana. J. Cell Biol. 26: 445-465.

Thomas, R. C. (1978) Ion-sensitive Intracellular Microelectrodes, Academic Press, London.

Triggle, D. J. and C. R. Triggle (1976) Quantitative aspects of ligand receptorinteractions. In Chemical Pharmacology of the Synapse, D. J. Triggle and C. R. Triggle, eds., pp. 129-231, Academic Press, New York.

Vogel, Z. and M. Nirenberg (1976) Localization of acetylcholine receptors during synaptogenesis in retina. Proc. Natl. Acad. Sci. U. S. A. 74: 32683272.

Wang, G. K. and J. Schmidt (1976) Receptors for $\alpha$-bungarotoxin in the developing visual system of the chick. Brain Res. 114: 524-529. 